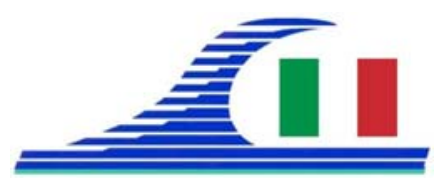

Conférence Méditerranéenne Côtière et Maritime EDITION 3, FERRARA, ITALIA (2015)

Coastal and Maritime Mediterranean Conference

Disponible en ligne - http://www.paralia.fr - Available online

\title{
Video based assessment of coastal erosion impact on beach attendance. Application to coastal management of Valras beach, France
}

\author{
Didier RIHOUEY ${ }^{1}$, Damien DAILLOUX ${ }^{1}$ \\ 1. CASAGEC INGENIERIE, 18 Rue Maryse bastié, 64600 Anglet, France. \\ rihouey@casagec.fr
}

\begin{abstract}
:
Shoreline stability is an important issue along much of the Mediterranean's Coasts where beach tourism represents one of the main economic resources. Hence, the evaluation of beach attendance is an important parameter to support coastal management planning in order to maintain the recreational capacity despite of coastal hazards increase. In the framework of the European project MEDDOOC INTERREG BEACHMED-e, a video system has been installed in 2008 to monitor the coastal environment of Valras (Gulf of Lion, France). This study presents a video based approach to assess the impact of coastal erosion on beach attendance. Mid-term beach retreat trend have been crossed with beach user quantification over a 7 years period. Results highlight beach attendance specificities of a coastline protected by breakwaters and show that recreational capacity could be significantly affected in the next decade.
\end{abstract}

Keywords: ICZM; Video monitoring; Shoreline evolution; Beach attendance.

\section{Introduction}

Coastal zones of the Mediterranean Sea are territory of particular interest for sustainable strategic development. Quantitative analysis of shoreline evolution and beach attendance plays an essential part in the integrated management of coastal zones. They are especially critical when planning coastal defence and assessing their efficiency. Over the past 30 years, video remote sensing has been developed into a very useful tool for sampling the nearshore environment (KROON et al., 2007). In the framework of this project, a video monitoring system has been installed in 2008 to monitor the coastal environment of Valras (Gulf of Lion, France). Valras is a beach resort located on the Gulf of Lion, Mediterranean Sea, France. The sandy beaches of Valras stretch between the Orb and the Aude river-mouth (Figure 1). The $3 \mathrm{~km}$ of Valras coastline are highly eroded since the building of the harbour jetty entrance in the $1960 \mathrm{~s}$. The longshore drift, induced by East wind storm, is stopped by this jetty located on the west side of the Orb river-mouth. Hence, important beach retreat has been observed and 12 breakwaters have been built until 2007. From January to May 2008, a similar protection, a submerged breakwaters, and, $95000 \mathrm{~m}^{3}$ sand nourishment, have been added. This study 
Côtes méditerranéennes menacées :

Risques et défis dans le contexte du changement climatique

aims to quantify mid-term beach evolution trend and beach attendance over a period of 7 year of video monitoring.

\section{Materials and methods}

\subsection{Video system}

Since December 2008, a video monitoring system, composed of 4 firewire cameras (0.8 Mega pixels, fixed optics), was installed on a top of a $47 \mathrm{~m}$ high building. The Valras station configuration aims to remotely monitor the shoreline over a $4 \mathrm{~km}$ radius. Inside this area, the cross-shore resolution is below $1 \mathrm{~m}$ per pixel, and the longshore resolution range from the centimeter (near the station) to $10 \mathrm{~m}$ (at the end of the domain). Figure 1 shows the final projected image merged from the 4 cameras images, and the remotely surveyed areas for this study decomposed in two zones (East and West).
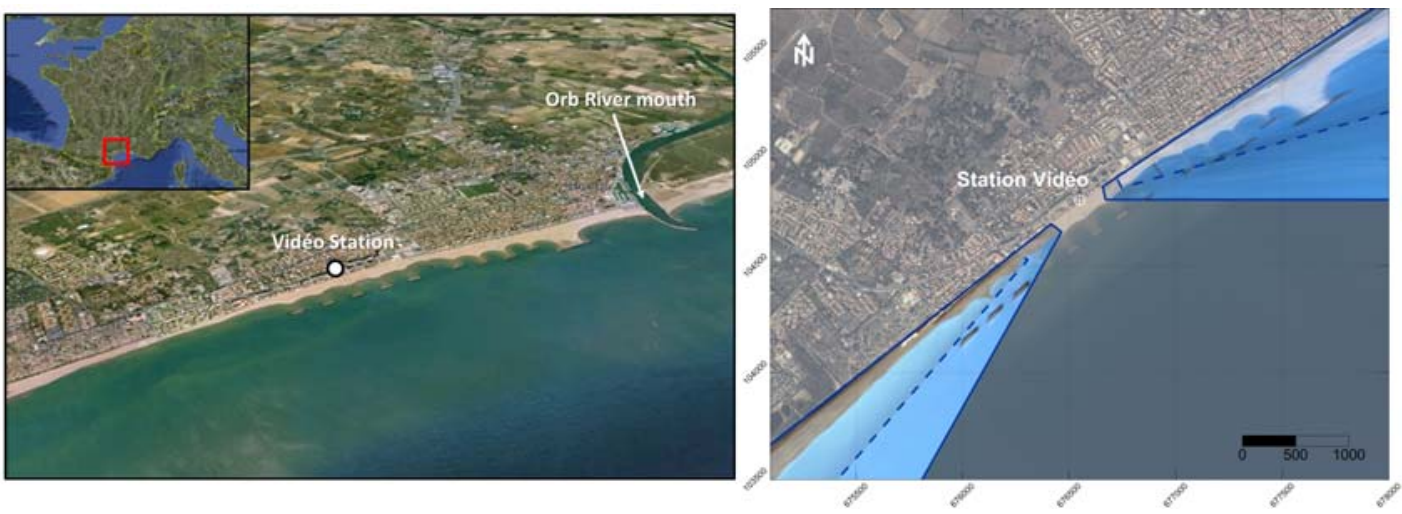

Figure 1. Field of study covered by the video monitoring system.

\subsection{Shoreline detection}

Images acquired by the video station usually show a strong contrast between blue sea water and yellow sandy beaches. Different algorithms have already been developed and proved their efficiency to automatically detect the position of the shoreline. In this study, the technique used is based on a mathematical approach. The RGB and HSV models are combined as six independent parameters treated by a clustering algorithm based on a k-mean function (MORICHON et al., 2008). Based on this technique, a series of shorelines were detected on rectified plan-view images. Images were selected during calm day (significant wave high below $60 \mathrm{~cm}$ ) and for a fixed sea water level according to a tidal gauge located closed to the surveyed area. Between January 2008 and September 2014, around 160 shoreline detections ( 2 per month) were performed. 


\subsection{Beach user quantification}

Over the past 10 years, several techniques have been developed to estimate beach usage from video systems (JIMENEZ et al., 2007; GUILLEN et al., 2008; BALOUIN et al., 2014). In this study we used a simple pixel-intensity based algorithm in order to estimate beach surface occupation from a region of interest (figure 2) and through segmentation techniques. Two types of information are collected on hourly bases: coordinates of each detected polygons, and global ground surface occupation (in $\mathrm{m}^{2}$ ) inside each region of interest. This information is used to extract occupation maps over the season, statistics of hourly to seasonal variation of occupation, etc. Between summer 2009 and summer 2014, a total of 14,000 images (7000 hours of monitoring) were treated to extract beach user information.
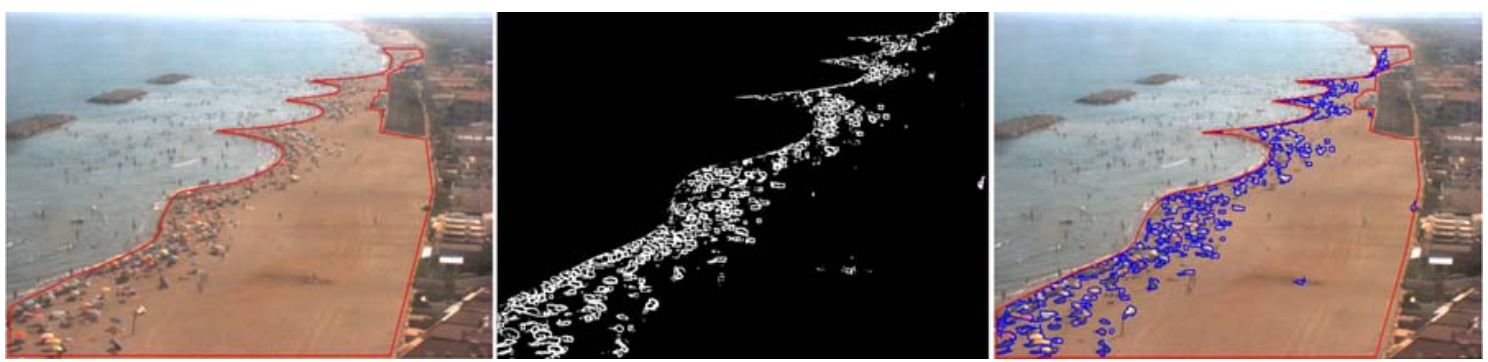

Figure 2. Pixel-intensity based algorithm for beach user detection.

\section{Results}

\subsection{Beach retreat}

The main result show an imbalance dynamic between the East zone, which present an important erosion rate (-2589 $\mathrm{m}^{2} /$ year), and the West zone where the beach surface tend to be stable over the period (figure 3). Looking at the Valras coastline, the disequilibrium is centred on the only groin present in the surveyed area, located $200 \mathrm{~m}$ east to the video station. Erosion rate increase from east to west until the groin location and then stop westward to this position. Thus the beach area surrounding the groin constitutes a major management issue.

\subsection{Beach attendance}

Statistical analyses of temporal beach attendance shows two daily pics centred on 11 AM and 5 PM. During summer, beach attendance increase from June to August and then rapidly decrease during September. From 2008 to 2014, the beach attendance continuously increase inside East zones (+ 60\% between 2009 and 2014), whereas the West zone shows decreasing trend, resulting from better beach access commodity (contrast between the urban East zone and the natural West zone). Spatial distribution of beach attendance inside the two zones point out that more than $90 \%$ of beach users are 
Côtes méditerranéennes menacées :

Risques et défis dans le contexte du changement climatique

concentred in a 20m large band, located close and along the coast line. The largest occupation zone is located near the groin where beach surface is the lowest.
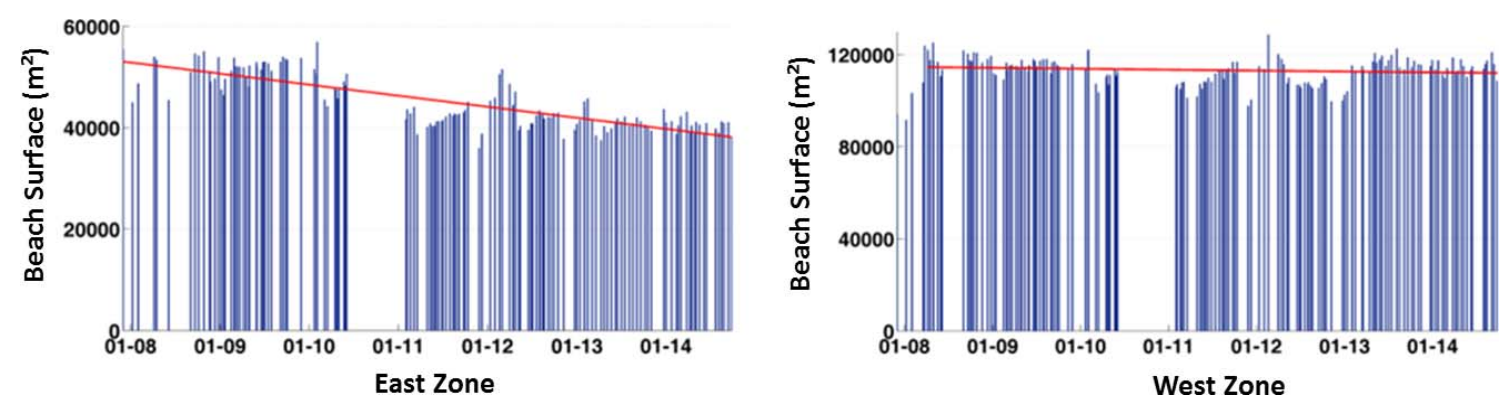

Figure 3. Beach surface evolution fot the East and the West zone (blue bar) and surface trend (red line).

\section{Conclusions}

The use of video system proved is efficiency as a provider of useful information for coastal management purpose. A substantial data set of 7 years of video monitoring allows for a clear definition of the beach evolution trend of Valras. Results show a strong erosion rate on the East part of the surveyed zone, with a highly sensitive area located near the presence of the groin. Crossing those results with beach attendance information shows that recreational capacity could be significantly affected in the next decade (figure 4). Hence, maritime works need to be carried out in this area. Replacing the groin with a breakwater and $25000 \mathrm{~m}^{3}$ sand nourishment, could be efficient solutions to keep beach attendance and reduce storm surge impact.
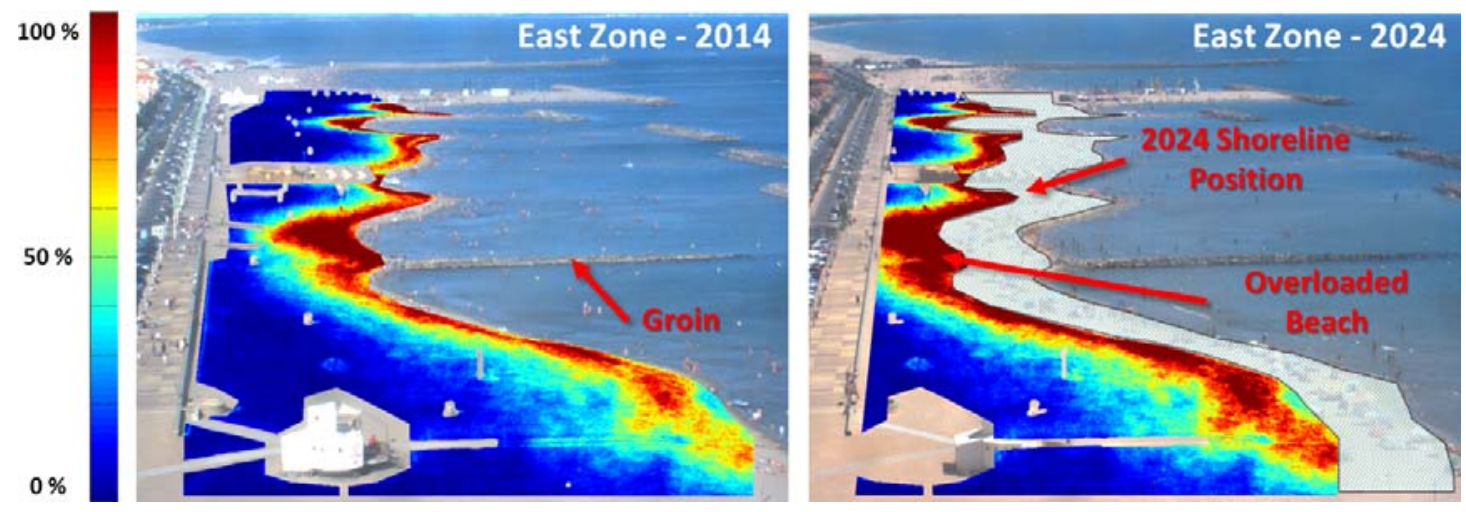

Figure 4. Actual average spatial distribution of beach user attendance (left). 2024 shoreline position according to video monitoring analysis crossed with beach user attendance results (right). 
Mediterranean coasts at threat:

Hazards and challenges in the context of climate variability

\section{Acknowledgments}

The authors acknowledge The Beachmed-e Project and the Hérault council (CG34) for the founding. We also want to thank the DRE of Languedoc Roussillon for tidal and wave data.

\section{References}

BALOUIN Y., REY-VALETTE H., PICAND P.A. (2014). Automatic assesment and analysis of beach attendance using video images at the Lido of Sète beach, France. Ocean \& Coastal Management, Vol. 102, pp 114-122.

http://dx.doi.org/10.1016/j.ocecoaman.2014.09.006

GUILLEN J., GARCIA-OLIVARES A., OJEDA E., OSORIO A., GONZALES R. (2008). Long-term quantification of beach users using video monitoring. Journal of Coastal Research, Vol. 24(6), pp 1612-1619. http://dx.doi.org/10.2112/07-0886.1

JIMENEZ J.A., OSORIO A., MARINO-TAPIA I., DAVIDSON M., MEDINA R., KROON A., ARCHETTI R., CIAVOLA P, AARNINKHOF S.G.J. (2007). Beach recreation planning using video-derived coastal state indicators. Coastal Engineering, Vol. 54(6-7), pp 507-521. http://dx.doi.org/10.1016/j.coastaleng.2007.01.012

KROON A., DAVIDSON M.A., AARNINKHOF S.G.J., ARCHETTI R., ARMAROLI, C., GONZALEZ M., MEDRI S., OSORIO A., AAGAARD T., HOLMAN R.A., SPANHOFF R. (2007). Application of remote sensing video systems to coastline management problems. Coastal Engineering, Vol. 54(6-7), pp 493-505. http://dx.doi.org/10.1016/j.coastaleng.2007.01.004

MORICHON D., DAILLOUX D., AARNINKHOF S., ABADIE S. (2007). Using a shore based video system to hourly monitor storm water plumes (Adour River, Bay of Biscay). Journal of Coastal Research, Vol. 24(4A), pp 133-140.

http://dx.doi.org/10.2112/06-0705.1 
Côtes méditerranéennes menacées :

Risques et défis dans le contexte du changement climatique 